\title{
KEANEKARAGAMAN JENIS VEGETASI PENYUSUN HUTAN MANGROVE DI DESA MEDAN MAS KABUPATEN KUBU RAYA
}

\author{
(The Diversity Of Species Vegetation Composer Of Mangrove Forest In Medan Mas Village \\ Kubu Raya Rigency)
}

\author{
Muhammad Nasir, Burhanuddin, Iswan Dewantara \\ Fakultas Kehutanan Universitas Tanjungpura Pontianak. Jl. Daya Nasional Pontianak 78124 \\ Email: aseownasir@gmailcom
}

\begin{abstract}
This study was conducted to determine the diversity of vegetation species that compose mangrove forests in the village of Medan Mas, Kubu Raya Regency. Measured parameters of important value index, dominance index $(C)$, species richness index $(R I)$, species evenness index (e) was carried out using the survey method by means of a plot. The placement of the research path was done (purposive). The path made in this study is 10 meters wide (5 $\mathrm{m}$ to the left $5 \mathrm{~m}$ to the right) and the path length is adjusted to the conditions in the field to the river boundary. From the pathway, a sub-plot is made with a size of $10 \mathrm{~m} \times 10 \mathrm{~m}$ for the tree level, and $5 \mathrm{~m} \times 5 \mathrm{~m}$ for the sapling level and $2 \times 2$ for the seedling level. The results of this study indicate that the types found in the field amounted to 12 species for seedlings, 10 species for saplings and 9 species for trees. Based on the results of the data obtained, it is known that the index value of species diversity $(H)$ at seedling, sapling and tree levels shows a number $<1$. This means that the value of species diversity found in mangrove forests in Medan Mas Village is relatively low. Forests with low species diversity values indicate that the forest area has experienced forest disturbance or damage. When data collection is carried out in the field, there are several locations that experience disruption or damage in the form of logged-over or transfer functions as shrimp ponds.
\end{abstract}

Keywords: Mangrove Forest, Vegetation Diversity,

\section{PENDAHULUAN}

Indonesia merupakan negara kepulauan, memiliki 17.504 pulau danpanjang garis pantai sekitar 95.181 $\mathrm{km}$ dengan kondisi biofisik lingkungan dan iklim beragam (Kusmana, 2011). Pada bagian wilayah pesisir Indonesia didominasi oleh ekosistem hutan mangrove. Menurut Suryono (2013) hutan mangrove merupakan istilah yang dipakai untuk menggambarkan suatu komunitas vegetasi pantai tropik yang didominasi oleh beberapa spesies pohon-pohon yang khas atau semak- semak yang mempunyai kemampuan untuk tumbuh dalam perairan asin.

Hutan mangrove memiliki keanekaragam jenis cukup tinggi, hal ini dapat dibuktikan dari hasil penelitian Prastomo et al. (2017) jumlah jenis yang ditemukan di kawasan hutan mangrove desa Nusapati kabupaten Mempawah berjumlah 11 jenis, diantaranya yaitu: Avicennia floridium, A. alba, A. lanata, A. marina, Bruguiera cylindrica, B. gymnorrhza, B.mparviflora, E. agallocha, S. alba, S. caseolaris, $X$. mollucensis. Hutan mangrove memiliki peran penting 
karena letak dan kondisinya yang strategis berada di pinggir pantai dan menghadap langsung ke laut, sehingga hutan mangrove berperan sebagai ekosistem penyanggah (buffer zone) (Rahmawati et al. 2014).

Desa Medan Mas Kecamatan Batu Ampar Kabupaten Kubu Raya memiliki hutan mangrove. Informasi mengenai komposisi vegetasi penyusun hutan mangrove di Desa Medan Mas belum tersedia. Dari hal tersebut di atas, sehingga dirasa perlu dilakukan penelitian mengenai komposisi vegetasi penyusun hutan mangrove di Desa Medan Mas Kabupaten Kubu Raya.

\section{METODE PENELITIAN}

Penelitian ini dilakukan selama 3 minggu di lapangan. Metode yang digunakan dalam penelitian ini adalah menggunakan metode survei dengan cara jalur berpetak (Kusmana, 1997). Penentuan jalur contoh penelitian dilakukan secara disengaja (purposive sampling) artinya jalur penelitian diletakkan sesuai dengan ditemukannya pohon mangrove di kawasan hutan tersebut. Jalur yang dibuat dalam penelitian ini dengan lebar 10 meter (5 $\mathrm{m}$ ke kiri $5 \mathrm{~m}$ ke kanan) dan panjang jalur disesuaikan pada kondisi di lapangan sampai ke batas sungai. Dari jalur tersebut dibuat sub-petak dengan ukuran $10 \mathrm{~m}$ x $10 \mathrm{~m}$ untuk tingkat pohon, dan $5 \mathrm{~m} \times 5 \mathrm{~m}$ untuk tingkat pancang dan 2 x 2 untuk tingkat semai.

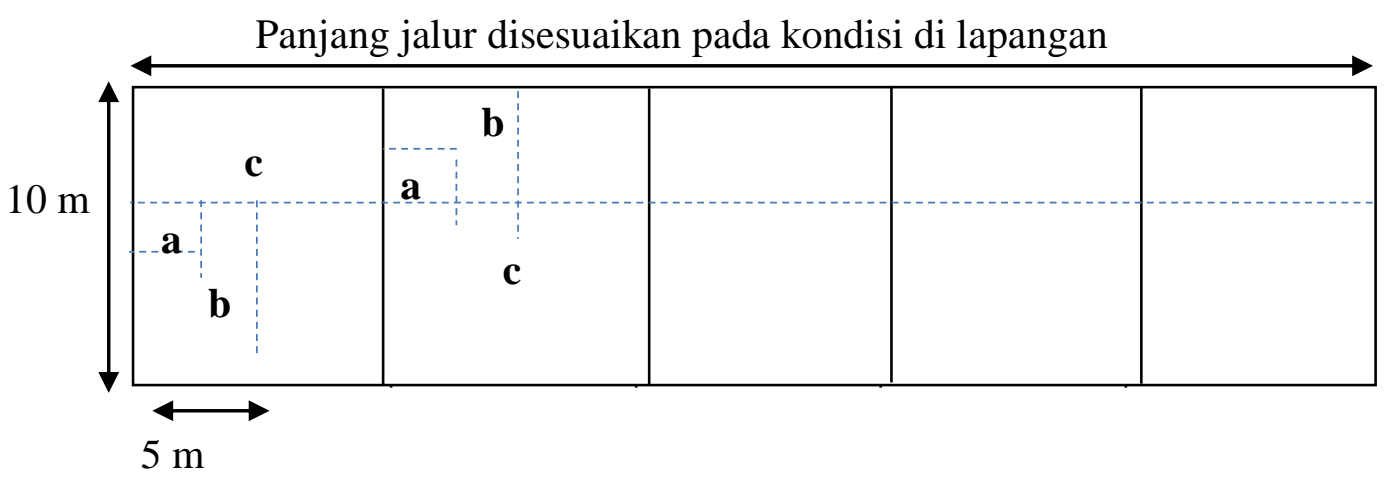

Gambar 1. Desain petak contoh di lapangan dengan metode jalur berpetak

Keterangan:

Sub-petak a = petak berukuran $2 \mathrm{~m} \times 2 \mathrm{~m}$ untuk pengamatan tingkat semai

Sub-petak $\mathrm{b}=$ petak berukuran $5 \mathrm{~m} \times 5 \mathrm{~m}$ untuk pengamatan tingkat pancang

Sub-petak $\mathrm{c}=$ petak berukuran $10 \mathrm{~m} \times 10 \mathrm{~m}$ untuk pengamatan tingkat pohon

1. Indeks Nilai Penting (INP)

Tingkat semai $=(\mathrm{INP}=\mathrm{KR}+\mathrm{FR})$

Tingkat pancang dan tingkat pohon $=$ $(\mathrm{INP}=\mathrm{KR}+\mathrm{FR}+\mathrm{DR})$

1) Densitas/Kerapatan (K)

$\mathrm{K}-\mathrm{i}=\frac{\text { Jumlah Individu untuk spesies } \mathrm{ke}-\mathrm{i}}{\text { luas seluruh petak contoh }}$
2) Kerapatan relatif (KR)

$\mathrm{KR}-\mathrm{i}=\frac{\text { Kerapatan spesies ke }-\mathrm{i}}{\text { Kerapatan seluruh spesies }} \quad \mathrm{X}$ $100 \%$

3) Frekuensi $(F)$ 


\section{$\mathrm{F}-\mathrm{i}=$}

$$
C=\sum_{i=1}^{n}(n i / N)^{2}
$$

Jumlah petak contoh ditemukannya suatu spesies kKKèterangan :

$$
\text { Jumlah seluruh petak contoh }
$$

4) Frekuensi Relatif (FR)

$$
\begin{aligned}
& \text { FR }-i=\frac{\text { Frekuensi suatu spesies ke- } \mathrm{i}}{\text { Frekuensi seluruh spesies }} \mathrm{x} \\
& 100 \%
\end{aligned}
$$

5) Dominasi (D)

$\mathrm{D}-\mathrm{i}=\frac{\text { Luas bidang dasar suatu spesies }}{\text { Luas petak contoh keseluiruhan }}$

6) Dominasi Relatif (DR)

$$
\begin{aligned}
& \mathrm{DR}-\mathrm{I}= \\
& \frac{\text { Dominasi suatu spesies }}{\text { Dominasi total seluruh spesies }} \times 100 \%
\end{aligned}
$$

2. Indeks Keanekaragaman (Index of

Diversity)

Keanekaragaman spesiesdihitung menggunakan rumus indeks Shannon $(\bar{H})$ sebagai berikut:

$$
\bar{H}=-\sum_{\mathrm{i}=1}^{\mathrm{n}}\left(\frac{n i}{N}\right) \log \left(\frac{n i}{N}\right)
$$

Keterangan :

$\bar{H}=$ indeks keanekaragaman spesies

$n i=$ nilai kepentingan untuk tiap spesies atau INP spesies ke-i

$N=$ nilai kepentingan total atau total INP

$P i=$ peluang kepentingan untuk tiap spesies $=n i / N$

3. Indeks Dominansi Jenis (C)

Indeks dominansi suatu spesies, dihitung menggunakan rumus sebagai berikut:
C = Indeks dominansi jenis

$n i=$ Nilai kepentingan untuk tiap spesies atau

INP spesies ke- $\mathrm{i}$

$N=$ Total nilai kepentingan atau total INP

4. Indeks Kekayaan Spesies (RI)

Kekayaan spesies dihitung menggunakan indeks Margalief (Ludwig dan Reynold, 1988), yaitu:

Keterangan :

$$
\mathrm{RI}=\frac{(S-1)}{\operatorname{In}(\mathrm{N})}
$$

RI= Indeks Kekayaan Margalief

$\mathrm{S}=$ Jumlah spesies yang ditemukan

$\mathrm{N}=$ Jumlah total individu

5. Indeks Kemerataan Spesies (e)

Indeks kemerataan spesies dihitung menggunakan rumus

$$
\mathrm{E}=\frac{\mathrm{H}^{\prime}}{\operatorname{In}(\mathrm{S})}
$$

Keterangan :

$\mathrm{E}=$ Indeks Kemerataan spesies

$\mathrm{H}^{\prime}=$ Indeks Keanekaragaman spesies

$\mathrm{S}=$ Jumlah spesies

\section{HASIL DAN PEMBAHASAN}

\section{Jumlah Jenis}

Hasil pengukuran dan pengamatan di lapangan, terdapat 12 jenis mangrove yang ditemukan. Guna lebih jelasnya dapat dilihat pada Tabel 1. 
Tabel 1. Jumlah Jenis yang Ditemukan di Lapangan. (Number of Types Found in the Field.)

\begin{tabular}{|c|c|c|c|c|c|c|}
\hline \multirow{2}{*}{ No } & \multirow{2}{*}{ Nama Ilmiah } & \multirow{2}{*}{ Nama Lokal } & \multicolumn{3}{|c|}{ Jumlah Individu/Ha } & \multirow{2}{*}{ Jumlah } \\
\hline & & & Semai & Pancang & Pohon & \\
\hline 1 & Aegiceras corniculatum & Teruntun & 5.500 & 614 & 160 & 6.274 \\
\hline 2 & Avicennia alba & Api-api & 5.526 & 729 & 170 & 6.425 \\
\hline 3 & Avicennia marina & Api-api putih & 5.938 & 590 & 168 & 6.696 \\
\hline 4 & Bruguiera gymnorrhiza & Tanjang merah & 5.694 & 565 & 163 & 6.422 \\
\hline 5 & Exoecaria agallocha & Buta-buta & 4.643 & 596 & 153 & 5.392 \\
\hline 6 & Ficus $s p$ & Beringin & 3.846 & 600 & - & 4.446 \\
\hline 7 & Lagerstroemia speciosa & Bungur & 3.125 & - & - & 3.125 \\
\hline 8 & Nypa fruticans & Nipah & 6.563 & - & - & 6.563 \\
\hline 9 & Rhizhopora apiculata & Bakau putih & 8.229 & 542 & 160 & 8.931 \\
\hline 10 & Rhizophora mucronata & Bakau hitam & 6.081 & 574 & 135 & 6.790 \\
\hline 11 & Sonneratia alba & Perepat & 5.385 & 604 & 153 & 6.142 \\
\hline 12 & Xylocarpus granatum & Niri & 6.190 & 541 & 145 & 6.876 \\
\hline \multicolumn{3}{|c|}{ Total Jumlah } & 66.720 & 5.955 & 1.407 & 85.540 \\
\hline
\end{tabular}

Sumber: Hasil analisis data lapangan, 2018

Dari Tabel 1 jumlah jenis yang ditemukan pada tingkat semai berjumlah 12 jenis, pada tingkat pancang berjumlah 10 jenis dan pada tingkat pohon berjumlah 9 jenis. jumlah individu yang ditemukan di lapangan bervariasi jumlahnya, terutama pada tingkat semai berjumlah 66.720 individu/ha, pada tingkat pancang berjumlah 5.955 individu/ha, sedangkan pada tingkat pohon berjumlah 1.407 individu/ha. Jumlah individu yang paling banyak ditemukan pada tingkat semai adalah jenis Rhizhopora apiculata sebanyak 8.229 individu/ha, pada tingkat pancang jumlah individu yang paling banyak ditemukan adalah jenis A. alba sebanyak 729 individu/ha, sedangkan pada tingkat pohon yang paling banyak ditemukan adalah jenis $A$. marina sebanyak 168 individu/ha.

Jumlah individu yang ditemukan pada masing-masing tingkat pertumbuhan di lapangan mengalami penurunan secara eksponensial seiring dengan bertambahnya kelas diameter. Ketersediaan individu/tegakan pada hutan bertipe normal sangat tinggi, sehingga dapat memperbaiki kondisi hutan serta dapat menjamin kelangsungan tegakan dimasa mendatang. Kehilangan pohon yang berdiameter besar dimasa mendatang akibat kerusakan atau kematian akan dapat digantikan oleh pohon yang berdiameter lebih kecil (Suwardi et al, 2013; Pratama et al, 2012).

\section{Indeks Nilai Penting (INP)}

Jenis dengan nilai INP tertinggi merupakan jenis yang mendominasi di komunitasnya, sehingga dengan melihat nilai INP suatu jenis, maka dapat diketahui pula jenis apa saja yang mendominasi pada suatu tegakan hutan. Nilai INP dari keseluruhan sub-petak penelitian dapat lihat pada Tabel 2. 
Tabel 2. Jumlah Individu dan Nilai INP Jenis Vegetasi Tingkat Semai, Pancang dan Pohon. (Individual Number and INP Value of Seedling, Stake and Tree Level Vegetation Types).

\begin{tabular}{|c|c|c|c|c|c|c|c|c|}
\hline \multirow{3}{*}{ No } & \multirow{3}{*}{ Nama Ilmiah } & \multirow{3}{*}{ Nama Lokal } & \multicolumn{6}{|c|}{ Tingakat Pertumbuhan } \\
\hline & & & \multicolumn{2}{|c|}{ Semai } & \multicolumn{2}{|c|}{ Pancang } & \multicolumn{2}{|c|}{ Pohon } \\
\hline & & & $\begin{array}{l}\sum_{/ \text {Ind }} \text { Ind } \\
\text {. }\end{array}$ & INP\% & $\begin{array}{l}\sum_{\text {/ha }} \text { Ind } \\
\text {. }\end{array}$ & INP\% & $\sum_{/ \text {ha }}$ Ind & INP\% \\
\hline 1 & Aegiceras corniculatum & Teruntun & 5.500 & 18,0152 & 614 & 16,0388 & 160 & 20,9448 \\
\hline 2 & Avicennia alba & Api-api & 5.526 & 17,1540 & 729 & 17,7888 & 170 & 14,6131 \\
\hline 3 & Avicennia marina & Api-api putih & 5.938 & 22,4499 & 590 & 12,2391 & 168 & 14,691 \\
\hline 4 & Bruguiera gymnorrhiza & Tanjang merah & 5.694 & 16,4909 & 565 & 55,9471 & 163 & 53,4941 \\
\hline 5 & Exoecaria agallocha & Buta-buta & 4.643 & 11,6601 & 596 & 31,7419 & 153 & 46,3025 \\
\hline 6 & Ficus $s p$ & Beringin & 3.846 & 10,0069 & 600 & 13,8817 & - & - \\
\hline 7 & Lagerstroemia speciosa & Bungur & 3.125 & 2,8506 & - & - & - & - \\
\hline 8 & Nypa fruticans & Nipah & 6.563 & 7,8793 & - & - & - & - \\
\hline 9 & Rhizhopora apiculata & Bakau putih & 8.229 & 26,8064 & 542 & 47,2147 & 160 & 49,203 \\
\hline 10 & Rhizophora mисronata & Bakau hitam & 6.081 & 35,0311 & 574 & 34,3625 & 135 & 37,1558 \\
\hline 11 & Sonneratia alba & Perepat & 5.385 & 11,5911 & 604 & 36,9106 & 153 & 26,4503 \\
\hline 12 & Xylocarpus granatum & Niri & 6.190 & 20,0645 & 541 & 33,8746 & 145 & 37,1454 \\
\hline \multicolumn{3}{|c|}{ Total Jumlah } & 66.720 & 200 & 5.955 & 300 & 1.407 & 300 \\
\hline
\end{tabular}

Sumber: Hasil analisis data lapangan, 2018

Dari Tabel 2 dapat dilihat INP tertinggi pada tingkat semai adalah jenis $R$. mucronata dengan nilai INP sebesar $28,57143 \%$, pada tingkat pancang jenis B. gymnorrhiza dengan nilai INP sebesar 55,9471\%, dan pada tingkat pohon jenis $B$. gymnorrhiza dengan nilai sebesar 53,4941\%. Semakin besar nilai INP suatu jenis, maka dapat dikatakan bahwa jenis itu mendominasi di daerah tersebut (Prastomo et al, 2017).

Jenis yang mendominasi suatu areal dinyatakan sebagaijenis yang memiliki kemampuan adaptasi dan toleransiyang lebar terhadap kondisi lingkungan. Suatu spesies dianggap dominan diindikasikan oleh indeksnilai penting, yaitu mempunyai nilai frekuensi, densitas dan dominansi lebih tinggi dibanding spesies lain (Sukarna, 2013; Arrijani, 2008). Indeks nilai penting suatu jenis memberikan gambaran bahwa keberadaan jenis tersebut semakin stabil atau berpeluanguntuk dapat mempertahankan pertumbuhan dan kelestarian jenisnya (Dendang dan Handayani, 2015). Suatu jenis tingkat semai bisa dikatakan berperan apabila memiliki INP > 10\%, sedangkan pada tingkat pancang dan pohon bisa dikatakan berperan apabila nilai INP > 15\% (Ferianita, 2006; Mawazin dan Subiakto, 2013).

\section{Indeks Dominansi Jenis (C)}

Indeks dominansi jenis merupakan suatu parameter yang dapat digunakan dalam suatu komunitas untuk menyatakan tingkat terpusatnya dominansi suatu spesies (Prastomo et al, 2017). Hasil analisis indeks dominansi jenis (C) vegetasi tingkat semai, pancang, dan pohon dapat dilihat pada Tabel 3. 
Tabel 3. Rekapitulasi Indeks Dominansi Jenis (C) Semai, Pancang dan Pohon. (Dominance Index Recapitulation of Types (C) Seedlings, Stakes and Trees).

\begin{tabular}{cllccc}
\hline \multirow{2}{*}{ No } & \multirow{2}{*}{ Nama Ilmiah } & \multicolumn{2}{c}{ Nama Lokal } & \multicolumn{2}{c}{ Indeks Dominansi Jenis (C) } \\
\cline { 4 - 6 } & & & Semai & Pancang & Pohon \\
\hline 1 & Aegiceras corniculatum & Teruntun & 0,0074 & 0,001776 & 0,002445 \\
2 & Avicennia alba & Api-api & 0,0068 & 0,001776 & 0,001422 \\
3 & Avicennia marina & Api-api putih & 0,0125 & 0,000986 & 0,001298 \\
4 & Bruguiera gymnorrhiza & Tanjang merah & 0,0064 & 0,013036 & 0,010978 \\
5 & Exoecaria agallocha & Buta-buta & 0,0026 & 0,005524 & 0,007746 \\
6 & Ficus sp & Beringin & 0,0015 & 0,001297 & - \\
7 & Lagerstroemia speciosa & Bungur & 0,0001 & - & - \\
8 & Nypa fruticans & Nipah & 0,0017 & - & - \\
9 & Rhizhopora apiculata & Bakau putih & 0,0242 & 0,008883 & 0,008971 \\
10 & Rhizophora mucronata & Bakau hitam & 0,0315 & 0,006473 & 0,007167 \\
11 & Sonneratia alba & Perepat & 0,003 & 0,006473 & 0,004384 \\
12 & Xylocarpus granatum & Niri & 0,0104 & 0,006722 & 0,006076 \\
\hline
\end{tabular}

Sumber: Hasil analisis data lapangan, 2018

Diketahui bahwa komunitas jenisjenis yang memiliki nilai $(\mathrm{C})$ tertinggi pada tingkat semai adalah jenis Rhizophora mucronata dengan nilai $\mathrm{C}=0,025497$, pada tingkat pancang jenis Bruguiera gymnorrhiza dengan nilai $\mathrm{C}=0,013036$ dan pada tingkat pohon terdapat pada jenis Bruguiera gymnorrhiza dengan nilai $\mathrm{C}=0,010978$. Hutan mangrove di Desa Medan Mas Kecamatan Batu Ampar pada seluruh tingkatan tidak dikuasai oleh satu jenis, melainkan cenderung mendominasi secara bersama-sama. Hal inidikarenakan nilai $\mathrm{C}$ pada tiap tingkat pertumbuhan mendekati nilai 0 (nol) atau rendah (Indriyanto, 2006). Hasil yang diperoleh peneliti sejalan dengan hasil penelitian Prastomo et al (2017) nilai $\mathrm{C}<0,5$ menunjukan bahwa pada komunitas hutan mangrove di Desa Nusapati Kabupaten Mempawah tidak hanya dikuasai oleh satu jenis tetapi mendominasi secara bersama-sama atau tidak terpusat pada satu jenis.

\section{Indeks Keanekaragaman Jenis $(\overline{\mathbf{H}})$}

Indeks keanekaragaman jenis merupakan suatu nilai yang menunjukkan keberagaman jenis yang ditemukan di lapangan. Semakin tinggi nilai indeks keanekaragaman jenis $(\mathrm{H})$, maka semakin banyak jenis-jenis yang terdapat pada kawasan tersebut. Menurut Ferianita (2007) kisaran indeks keanekaragaman jenis $(\mathrm{H})$ antara 1-3. Kisaran nilai $\mathrm{H}<1$ berarti keanekaragaman rendah, jika $\mathrm{H} 1-<3$ berarti keanekaragaman sedang dan jika $\mathrm{H}>3$ berarti keanekaragaman tinggi.

Berdasarkan data yang diketahui bahwa nilai indeks keanekaragaman jenis $(\mathrm{H})$ pada tingkat semai, pancang dan pohon menunjukkan angka $<1$. Hal ini berarti nilai kelimpahan jenis yang terdapat pada hutan mangrove di Desa Medan Mas tergolong rendah. Hutan dengan nilai keragaman jenis rendah menunjukkan pada kawasan hutan tersebut pernah mengalami gangguan atau kerusakan hutan. Saat dilakukan pengambilan data di lapangan, terdapat beberapa lokasi yang mengalami 
gangguan atau kerusakan berupa bekas tebangan maupun alih fungsi sebagai tambak udang. Kusmana dan Susanti (2014) menyebutkan faktor lain yang dapat mempengaruhi keanekaragaman spesies tumbuhan pada suatu kawasan yaitu: bahan organik tanah, kelengasan tanah, ph tanah, suhu, dan intensitas cahaya. Tumbuhan memiliki tingkattoleransi tertentu terhadap kondisi lingkungannya agar tetap hidup dan berkembang. Jikakondisi lingkungan berubah melebihi tingkat toleransinya, maka akan menyebabkan kemusnahan tumbuhan dari habitat tersebut.

\section{Indeks Kemerataan Jenis (e)}

Indeks kemerataan jenis (e) dipengaruhi oleh besarnya nilai keanekaragaman suatu jenis dan jumlah seluruh jenis. Artinya semakin tinggi nilai kelimpahan jenis maka penyebaran suatu jenis semakin merata dalam suatu kawasan, begitu pula sebaliknya. Menurut Odum (1993) indeks kemerataan jenis (e) berkisar antara 0-1, jika e > 1, maka seluruh jenis yang ada memiliki kelimpahan yang tidak merata, sedangkan jika e $<1$, maka seluruh jenis yang ada kelimpahan merata. Hasil penghitungan indeks kemerataan jenis di hutan mangrove Desa Medan Mas Kecamatan Batu Ampar dapat dilihat pada Tabel 5.

Tabel 4. Rekapitulasi Indeks Kemerataan Jenis (e) Tingkat Semai, Pancang dan Pohon. (Evenness Index Type (e) Recapitulation of Seedlings, Stakes and Trees).

\begin{tabular}{cllccc}
\hline \multirow{2}{*}{ No } & \multirow{2}{*}{ Nama Ilmiah } & \multirow{2}{*}{ Nama Lokal } & \multicolumn{2}{c}{ Indeks Kemerataan Jenis (e) } \\
\cline { 4 - 6 } & & & Semai & Pancang & Pohon \\
\hline 1 & Aegiceras corniculatum & Teruntun & 0,0873 & 0,042032 & 0,063288 \\
2 & Avicennia alba & Api-api & 0,0848 & 0,048327 & 0,038896 \\
3 & Avicennia marina & Api-api putih & 0,0988 & 0,029364 & 0,039172 \\
4 & Bruguiera gymnorrhiza & Tanjang merah & 0,0828 & 0,255696 & 0,249547 \\
5 & Exoecaria agallocha & Buta-buta & 0,0667 & 0,108465 & 0,199309 \\
6 & Ficus sp & Beringin & 0,0603 & 0,034669 & - \\
7 & Lagerstroemia speciosa & Bungur & 0,0244 & - & - \\
8 & Nypa fruticans & Nipah & 0,0513 & - & - \\
9 & Rhizhopora apiculata & Bakau putih & 0,1084 & 0,195983 & 0,218913 \\
10 & Rhizophora mucronata & Bakau hitam & 0,1228 & 0,121719 & 0,143085 \\
11 & Sonneratia alba & Perepat & 0,0664 & 0,135208 & 0,087604 \\
12 & Xylocarpus granatum & Niri & 0,0928 & 0,119204 & 0,143026 \\
\hline
\end{tabular}

Sumber: Hasil analisis data lapangan, 2018

Hasil analisis perhitungan nilai kemerataan jenis Tabel 5, dapat diketahui pada tingkat semai, pancang dan pohon pada vegetasi mangrove memiliki nilai $<1$. Nilai tersebut menunjukkan bahwa vegetasi hutan mangrove di Desa Medan Mas memiliki kelimpahan tidak merata. Hal ini sejalan dengan hasil penelitian yang dilakukan oleh Prastomo et al (2017) pada hutan mangrove di Desa Nusapati, nilai kemerataan yang diperoleh $<1$. Menurut Prastomo et al (2017) nilai kelimpahan yang tidak merata 
menunjukkan bahwa dalam setiap subpetak penelitian yang diamati, tidak setiap petak selalu memiliki jenis yang sama.

\section{Indeks Kekayaan Jenis (RI)}

Indeks kekayaan adalah indeks yang menunjukan kekayaan jenis dalam suatu komunitas. Besarnya nilai kekayaan spesies dapat dipengaruhi oleh banyaknya jumlah spesies/jenis dan jumlah individu dalam suatu komunitas. Menurut Magurran (1988) besaran indeks kekayaan spesies (RI) apabila nilai < 3,5 menunjukan kekayaan jenis tergolong rendah, apabila nilai > 3,5 - 5,0 tergolong sedang, apabila nilai > 5,0 menunjukan kekayaan jenis tergolong tinggi. Nilai indeks kekayaan dapat dihitung berdasarkan tingkat pertumbuhan mulai dari semai, pancang dan pohon. Hasil penghitungan indeks kekayaan spesies di hutan mangrove Desa Medan Mas dapat dilihat pada Tabel 6 .

Tabel 5. Rekapitulasi Indeks Kekayaan Jenis (RI) Semai, Pancang dan Pohon. (Wealth, Tree and Tree (RI) Wealth Index Recapitulation).

\begin{tabular}{clc}
\hline No & \multicolumn{1}{c}{ Tingkat Pertumbuhan } & Indeks Kekayaan Jenis (RI) \\
\hline 1 & Semai & 4,1 \\
2 & Pancang & 3,2 \\
3 & Pohon & 2,9 \\
\hline
\end{tabular}

Sumber: Hasil analisis data lapangan, 2018

Hasil perhitungan indeks kekayaan jenis (RI) tertuang dalam Tabel 6 dapat dilihat adanya variasi nilai kekayaan jenis pada tingkat pertumbuhan berbeda. Indeks kekayaan jenis tertinggi terdapat pada tingkat pertumbuhan semai dengan nilai 4,1. Hal ini mengindikasikan bahwa pada tingkat semai nilai kekayaan jenis tergolong sedang, sedangkan pada tingkat pancang dan pohon berkisar antara 2,93,2. Hal ini menunjukkan bahwa pada tingkat pancang dan pohon nilai kekayaan jenis tergolong rendah.

Indeks kekayaan jenis sangat berperan dalam menentukan nilai keanekaragaman jenis. Hal ini disebutkan Wijana (2014) bahwa keanekaragaman jenis dipengaruhi oleh nilai kemerataan jenis (E) dan kekayaan jenis (RI) dan diantara kedua komponen tersebut, masing-masing memiliki indeks tertentu. Nilai indeks kekayaan jenis sama atau mendekati sama, maka antara kemerataan jenis dan kekayaan jenis yang menentukan indeks keanekaragaman memiliki kontribusi yang sama atau seimbang dan apabila hal itu terjadi sebaliknya, maka salah satu komponen memberikan kontribusi yang lebih besar.

\section{Kesimpulan}

Kesimpulan yang diperoleh dari penelitian ini adalah :

1) Jumlah jenis yang ditemukan pada tingkat semai berjumlah 12 jenis dengan jumlah individu sebesar 66.720 individu/ha, pada tingkat pancang jumlah jenis yang ditemukan sebesar 10 jenis dengan jumlah individu sebesar 5.955 individu/ha, dan pada pohon berjumlah 9 jenis dnegan jumlah individu sebesar 1.407 individu/ha. 
2) INP tertinggi pada tingkat semai jenis Rhizophora mucronata dengan nilai INP sebesar 28,57143\%, pada tingkat pancang jenis Bruguiera gymnorrhiza dengan nilai INP sebesar 55,9471\%, dan pada tingkat pohon jenis Bruguiera gymnorrhiza dengan nilai sebesar 53,4941\%.

3) Indeks dominansi (C) tertinggi pada tingkat semai jenis Rhizophora mucronata dengan nilai $\mathrm{C}=0,025497$, pada tingkat pancang jenis Bruguiera gymnorrhiza dengan nilai $\mathrm{C}=0,013036$ dan pada tingkat pohon jenis Bruguiera gymnorrhiza dengan nilai $\mathrm{C}=0,010978$.

4) Nilai indeks keanekaragaman jenis $(\bar{H})$ pada tingkat semai, pancang dan pohon menunjukkan angka $<1$, hal ini mengindikasikan keanekaragaman jenis di hutan mangrove di Desa Medan Mas tergolong rendah.

5) Nilai kemerataan vegetasi mangrove di Desa Medan Mas menunjukkan nilai $<1$, nilai tersebut menunjukkan bahwa vegetasi hutan mangrove di Desa Medan Mas memiliki kelimpahan tidak merata.

6) Indeks kekayaan jenis pada tingkat semai tergolong sedang dengan nilai 4,1 sedangkan pada tingkat pancang dan pohon tegolong rendah dengan nilai $2,9-3,2$.

\section{Saran}

Saran yang dapat disampaikan dari penelitian ini adalah : Hutan mangrove Desa Medan Mas masih tergolong bagus sehingga keberadaannya perlu dipertahankan untuk menjaga kelestarian jenis mangrove yang terdapat di dalamnya.

\section{DAFTAR PUSTAKA}

Arrijani. 2008. Struktur dan Komposisi Vegetasi Zona Montana Taman Nasional Gunung Gede Pangrango. Jurnal Biodiversitas 9 (02) : 134-141.

Astiani D. 2016. Tropical Peatland Tree-Species Diversity Altered by Forest Degradation. Jurnal Biodiversitas. 17 (01) : 102-109.

Bismark M, Subiandono E, Herianto NM.2008. Keragaman dan Potensi Jenis Serta Kandungan Karbon Hutan Mangrove di Sungai Subelen Siberut, Sumatera Barat. Jurnal Penelitian Hutan dan Konservasi Alam 5 (03) : 297306.

Ferianita M. 2006. Metode Sampling Bioekologi. Penerbit PT Bumi Aksara. Jakarta.

Indriyanto. 2006. Ekologi Hutan. Jakarta: Penerbit PT Bumi Aksara.

Kusmana C. 2011. Management Of Mangrove Ecosystem In Indonesia. Fakultas Kehutanan IPB. Bogor.JPSL (1) 2 : 152 157.

Kusmana C. 1997. Metode Survei Lokasi. Institud Pertanian Bogor. Bogor.

Kusmana C, Susanti S. 2014. Komposisi dan Struktur Tegakan Hutan Alam di Hutan Pendidikan Gunung Walat Jawa Barat. Jurnal Silvikultur Tropika. 5 (03): 210217.

Ludwiq J A. Reynolds J F. 1988. Statistical Ecology a Primer on 
Methods and Computing, John Wiley \& Sons, New York.

Mawazin, Subiakto A. 2013. Keanekaragaman dan Komposisi Jenis Permudaan Alam Hutan Rawa Gambut Bekas Tebangan di Riau. Jurnal Indonesian Forest Rehabilitation 1 (01) : 59-73.

Odum E. 1993. Dasar-Dasar Ekologi. Terjemahan Oleh Tjahjono Samingan Dari Buku Fundamentals Of Ecology. Yogyakarta: Gajah Mada University Press.

Prastomo RH, Herawatiningsih R, Latifah S. 2017. Keanekaragaman Vegetasi di Kawasan Hutan Mngrove Desa Nusapati Kabupaten Mempawah. Jurnal Hutan Lestari 5 (2) : 556 - 562.

Pratama BA, Alhamd L, Rahajoe JS. 2012. Asosiasi dan Karakterisasi Tegakan pada Hutan Rawa Gambut di Hampangen, Kalimantan Tengah. J. Tek. Ling : 69-76.

Rahmawati D, Setyobudiandi I, Hilmi E. 2014. Potensi Estimasi Karbon Tersimpan Pada Vegetasi Mangrove di Wilayah Pesisir Muara Gembong Kabupaten Bekasi. Jurnal Omni-Akuatika 13 (19) : 85-91.

Suryono A. 2013. Sukses Usaha Pembibitan Mangrove Sang Penyelamat Pulau. Penerbit Pustaka Baru Bantul. Yogyakarta.

Sukarna RM. 2013. Perubahan Struktur dan Komposisi Hutan Rawa Gambut Menggunakan Citra Penginderaan Jauh Dan Pendekatan Ekologis Di Kawasan Bekas Pengembangan Lahan
Gambut Provinsi Kalimantan Tengah. Jurnal Ilmu Kehutanan 7 (02) : $129-146$. 